\title{
INTERNAL DYNAMICS WITHIN HADHRAMI ARABS IN INDONESIA From Social Hierarchy to Islamic Doctrine
}

\author{
Syamsul Rijal \\ UIN Antasari Banjarmasin - Indonesia | syamijal@yahoo.com
}

\begin{abstract}
This paper examines the current landscape of Hadhrami Arab Community in Indonesia. It aims to understand the internal fissures that affect the cohesion within the community. Some scholars contended that the conflicts taking place within the Hadhrami community are due to the Yemeni traditional stratification and nationalist orientation during colonial era. However, they do not include in their analysis the contemporary state of Hadhramis in Indonesia. This paper focuses on the contemporary era and argues that doctrinal contest and competition for religious authority have dominated the dynamics of conflict within Indonesian Hadhrami community. The paper will touch on the debates on the notion of Shi'ism among the so-called sayyids and Salafism among the followers of Al-Irsyad Al-Islamiyyah. It suggests that it is through these two currents of thought that the Hadhrami community in Indonesia not only exercise their power and authority, but also shape and transform their very identity.
\end{abstract}

Keywords: Hadhrami, Conflict, Sunni-Shi'a, Salafi.

\section{Introduction}

Since the early $20^{\text {th }}$ century, Hadhrami communities in the Netherlands East Indies have experienced a changing relationship within their own communities. The traditional social stratas, which had been transplanted to the Indies from Yemen, came under growing challenge. The dispute over the sayyid privileged status divided Hadhrami into conservative and reformist groups. Jamiat Khair and Rabithah Alawiyah represented the former, while Al-Irsyad represented 
the latter. These groups continue to exist today. Several scholars have analysed the changing identities of Hadhrami community during colonial era. ${ }^{1}$ However, the contemporary relationship within the community has attracted few scholars. ${ }^{2}$ In the contemporary era where Hadhrami have become more integrated to Indonesian society, there have been few studies on the conflicts taking place within this community. The community has currently experienced internal division over doctrinal issue due to the influences of Shi'ism and Salafism which have infiltrated into the community in the past couple decades. The conversion of Hadhrami individuals to Shi'ism has caused a division within the sayyid community, just as the influence of Salafism has brought a tension among the non-sayyids who affiliated with Al-Irsyad.

This paper explores the current landscape of the Hadhrami community by examining the contestation occurring from colonial to post-colonial Indonesia. It aims to understand the internal fissures that affect the cohesion within the community. It analyses factors that have united or divided the community in contemporary Indonesia. It argues that while the conflict in the colonial-era centred around the issue of Hadhrami traditional hierarchy and nationalist orientation, the current conflict has been largely concentrating on the competition of religious authority. Such conflict involves those Hadhrami-sayyids who adhere to Sunnism and Shi'sm as well as those who belong to al-Irsyad group, i.e

\footnotetext{
${ }^{1}$ See Husain Haikal, Indonesia-Arab dalam Pergerakan Kemerdekaan Indonesia (1900-1942) (Unpublished $\mathrm{PhD}$ Thesis, The University of Indonesia, Jakarta, 1986); Huub de Jonge, "Discord and Solidarity Among the Arabs in the Netherlands East Indies, 19001942," Indonesia, 55 (April 1930); Natalie Mobinie-Kesheh, The Hadhrami Awakening: Community and Identity in the Netherlands East Indies, 1900-1942 (New York: Cornell Southeast Asia Program, 1999).

2 See for instance Martin Slama, "Indonesian Hadhramis and the Hadhramaut: An Old Diaspora and Its New Connections," Antropologi Indonesia, 29: 1 (2005): pp. 107-113; Slama, "Paths of Institutionalization, Varying Divisions, and Contested Radicalism: Comparing Hadhrami Communities on Java and Sulawesi," Comparative Studies of South Asia, Africa, and the Middle East, 31: 2 (2011): pp. 331-342; Slama, "Hadhrami Moderns: Recurrent Dynamics as Historical Rhymes of Indonesia's Reformist Islamic Organizations Al-Irsyad, in Volker Gottowijk (ed.), Dynamics of Religion in Southeast Asia: Magic and Modernity (Amsterdam: Amsterdam University Press, 2014), pp. 113-133; Chaedar S. Bamualim, "Islamic Militancy and Resentment against Hadhramis in PostSuharto Indonesia: A Case Study of Habib Rizieq Syihab and His Islamic Defenders Front," Comparative Studies of South Asia, Africa, and the Middle East, 31: 2 (2011), pp. 267-281.
} 
Al-Irsyad Al-Islamiyah and Perhimpunan Al-Irsyad. Both sayyid and Irsyadi feel that their religious and cultural identity has been challenged by Shi'a and Salafi, the result of which being that the two groups are forced to reassert their very religious and communal identity.

The first part of this paper provides a short background of Hadhramis and their stratification system in Hadhramawt. The second part discusses the internal conflict among Hadhrami in the Netherlands East Indies that occurred between sayyid and Irsyadi communities. The last part examines the current discord within Hadhrami communities by comparing internal conflict in both sayyid and Irsyadi community. It also analyses factors that caused a friction and tension within each Hadhrami group.

\section{Hadhrami and Social Grouping in Hadhramawt}

Majority of Arab communities in Indonesia originally came from Hadhramawt. Hadhrami society comprises several groups who "largely married among themselves, shared a common array of occupational statuses, and bore tangible and intangible markers of group identification." 3 According to Bujra, stratification is an important aspect of the society. ${ }^{4}$ The stratification system of the Hadhrami community divides the population into three general stratum based on their descent: the sayyid (or säda, syeds, alawiyyin, ba'alawi, or habäib); mashäikh (scholars) and qabäil (tribesmen); and the masäkin (poor) and du'afä' (weak). ${ }^{5}$ The top class among the social groups is the sayyid. The group consists of people who claim to be descendants of the Prophet Muhammad through the line of his grandson Husayn. This group is considered to have the strongest lineage and highest religious status in the society. ${ }^{6}$

Due to their noble lineage, the sayyid came to be revered in Hadhramawt as teachers of Islam, imams (prayer leaders), and mediators in tribal conflicts. The sayyid were distinguished symbolically from other groups by receiving the honorifics sayyid (literally "master")

\footnotetext{
${ }^{3}$ Linda Boxberger, On the Edge of Empire: Hadhramaut, Emigration, and the Indian Ocean 1880s-1930s (Albany: State University of New York Press, 2002), p. 17.

${ }^{4}$ Abdullah S. Bujra, The Politics of Stratification: The Study of Political Change in a South Arabian Town (London: Oxford University Press, 1971), p. xiv.

5 Ibid., p. 13; Mobini-Kesheh, The Hadrami Awakening, p. 25.

${ }^{6}$ Bujra, The Politics of Stratification, p. 13.
} 
or habib (beloved) for men and sharifa, habiba, or sayyida for women. ${ }^{7}$ The community also showed respect by kissing their hands (taqbil) and greeting them before others in social and religious settings. ${ }^{8}$

The second stratum in Hadhrami society included the mashaikh (scholars) and qabail (tribesmen). Both groups traced their descent from a distant ancestor known as Qahtān, the eponymous ancestor of the Southern Arab. ${ }^{9}$ They enjoyed their status as religious elites and leaders in Hadhramawt before the coming of sayyids, who displaced them as the pre-eminent religious leaders. Qabail (sing. qabila) are tribesmen who "occupied and controlled most of the countryside, carried arms, and were considered less devout."10 Lineage has defined the identity and affiliation of tribal members, and with blood connection they are expected to receive mutual support and protection. ${ }^{11}$ This group is also known for the high importance they placed on sharaf (honor), which was associated with the ability to bear arms and defend one self and one's family. ${ }^{12}$ The best example of qabāil is the Kāthirī and Qu'aytī, two ruling tribes which competed for power in historical Yemen.

The third level of stratification was occupied by the masäkin (poor) and du'afä' (weak). They have neither descent connection to the Prophet nor to al-Qahtān. They also had no ancestors who served as religious leaders. ${ }^{13}$ The lowest stratum among all was occupied by 'abid (slaves) who were of African origin and had been brought to Yemen in 1860s. Some of them served as soldiers under the Qu'aytī and Kāthirī sultanate, while others served as household servants under private families. ${ }^{14}$

\footnotetext{
${ }^{7}$ Mobini-Kesheh, The Hadrami Awakening, p. 25; Boxberger, On the Edge of Empire, p. 20.

${ }^{8}$ Boxberger, On the Edge of Empire, p. 21.

9 Anne K. Bang, Sufi and Scholars of the Sea: Family Networks in East Africa 1860-1925 (London: Routledge, 2003), p. 13.

10 Mobini-Kesheh, The Hadrami Awakening, p. 25.

11 Boxberger, On the Edge of Empire, p. 25.

12 Mobini-Kesheh, The Hadrami Awakening, p. 25, Boxberger, On the Edge of Empire, p. 26.

${ }^{13}$ Bujra, The Politics of Stratification, p. 14.

${ }^{14}$ Boxberger, On the Edge of Empire, pp. 34-35.
} 


\section{Hadhrami and Internal Conflict in Colonial Indonesia}

The identity of the Hadhrami in the Netherland East Indies was shaped by social-political factors related to both domestic and global developments. The colonial system in Indonesia as well as the spread of Islamic reformism in the $20^{\text {th }}$ century influenced the undermining of the stratification system of Hadhrami. The sayyid group, who enjoyed elevated religious and social status from their fellow Hadhrami and local Muslim societies, were caught up in such developments. This happened against the backdrop of the Hadhrami awakening (nahdah hadhramiyyah) at the dawn of the twentieth century. ${ }^{15}$ In colonial times, the Hadhrami community was categorized as Foreign Orientals and considered below the European class, but above the 'natives'. They were also subject to Dutch policies that limited their mobility. ${ }^{16}$ The Hadhrami awakening aimed to bring awareness to Arabs regarding social equality and progress by adopting modern ideas and institutions. In the early $20^{\text {th }}$ century, the Hadhrami came to assert their belonging and allegiance to their homeland, Hadhramawt. ${ }^{17}$

There were three modern social institutions that characterized the Hahrami awakening: voluntary organisations, modern schools and newspapers. ${ }^{18}$ The earliest enactment of Hadhrami awakening was the establishment of the first modern organization for their community, Jamiat Khair (the Association for the Good) in Batavia in 1901. The founders of the organisation were sayyid, but in the leadership structure there were a few non-sayyid. Since the core program of the organisation lay in the field of education, they established Islamic schools in Batavia and Bogor that adopted a modern approach with text books, and Western sciences, as well maintaining the teaching of traditional religious subjects. ${ }^{19}$ To ensure the quality of religious studies and Arabic, they recruited a number of teachers from the Middle East. ${ }^{20}$

\footnotetext{
${ }^{15}$ Mobini-Kesheh, The Hadrami Awakening, p. 34.

${ }^{16}$ Jonge, Discord and Solidarity, p. 79.

${ }^{17}$ Mobini-Kesheh, The Hadrami Awakening, p. 34

18 Mobini-Kesheh, "Islamic Modernism in Colonial Java: The Al-Irshad Movement," in Ulrike Freitag and William G. Clarence-Smith, Hadhrami Traders, Scholars and Statesmen in The Indian Ocean, 1750s-1960s (Leiden: E.J. Brill, 1997), p. 233.

${ }^{19}$ Ibid.

${ }^{20}$ Deliar Noer, Gerakan Modern Islam di Indonesia 1900-1942 (Jakarta: LP3ES, 1980), p. 69.
} 
Discord among Hadhramis started when teachers recruited from the Middle East came to teach in the Jamiat Khair School. The most influential figure was the Sudanese Ahmad Surkati who had studied and taught in Mecca. During his long stay in Mecca, Surkati adopted the Egyptian ideas of Islamic reformism and became active in the modernist movement. ${ }^{21}$ The idea of Islamic reformism was propagated by Egyptian reformers such as Jamal al-Din al-Afghani (1838-1897), Muhammad 'Abduh (1849-1905), and Rashid Rida (1865-1935) at a time when the Muslim world was largely under European colonialism. The main aspiration of this movement was to reform Islam from within, arguing that the decline of Islamic civilization was due to the degeneration and corruption of Islam. It therefore promoted a return to the poor sources of Islam, the Qur'an and Hadith, while adopting the modern development. ${ }^{22}$ Surkati came to take up a position as inspector of Jamiat Khair schools, thereby contributing to the growth of the schools. He and other intellectuals infused the spirit of Islamic reformism in the schools. His reformist view became the immediate cause of conflict within the Hadhrami society. In 1912, he went to Solo to visit his friend, Awad Sungkar Al-Urmei. In a meeting with his friend he was told about a female sayyid (sharifa) in Solo who lived with a Chinese man outside marriage due to economic reasons. Surkati suggested helping the sharifa by separating her from her partner and seeking a Muslim man to marry her. Asked about the marriage status between a sharifa and a non-sayyid, he pronounced that such marriage is allowed according to Islamic law. ${ }^{23}$ On another occasion, he criticized the practice of hand kissing for sayyids and attacked what he saw as the self-exaltation and delusion of their holiness. ${ }^{24}$ His views aroused indignation among conservative sayyid leaders of Jamiat Khair in Batavia eventually forcing Surkati to resign from his position in Jamiat Khair. ${ }^{25}$

\footnotetext{
${ }^{21}$ Jonge, Discord and Solidarity, p. 81; Mobini-Kesheh, The Hadrami Awakening, p. 54.

22 Oliver Leaman, The Biographical Encyclopaedia of Islamic Philosophy (London: Bloomsbury, 2006), p. 108.

${ }^{23}$ Hussein Badjerei, Al-Irsyad Mengisi Sejarah Bangsa (Jakarta: Presto Prima Utama, 1996), pp. 28-29.

${ }^{24}$ Jonge, Discord and Solidarity, p. 81.

${ }^{25}$ Mobini-Kesheh, The Hadrami Awakening, p. 55.
} 
The resignation of Surkati triggered a deeper division within the Hadhrami community and led to the creation of new Hadhrami organisation with a reformist outlook. He gained support mostly from non-sayyids. Persuaded by reform-minded Hadhrami, most notably the Arab kapitein (a community leader appointed by the Dutch) Syaikh Umar Yusuf Umar Manggus, Surkati cancelled his intention to return to Mecca and later founded his own school, Madrasah al-Irsyad alIslamiyyah (Islamic School for Guidance). ${ }^{26}$ Following this, in 1914 Surkati and his friends established an organisation for supporting the operation of the schools under the name Jam'iyyah al-Islāh wa alIrsyād al-'Arabiyyah (Arab Association for Reform and Guidance). ${ }^{27}$ Echoing the reformist movement in Egypt, Al-Irsyad sought to purify Islam of superstition and innovations as result of its interaction with localities, and return to the religious foundation i.e. the Qur'an and the Hadith. At the Arab community level, the organisation strove to abolish the traditional Hadhrami stratification system that was inherited from Hadhramawt. ${ }^{28}$

The rapid development of Al-Irsyad and its continuing challenge to sayyids created a long period of hostility between them. Established in Batavia, Al-Irsyad spread rapidly to other cities in Java and islands of the Indies. As a response to the success of Al-Irsyad, in 1927 several sayyid established an organisation for their community called Rabithah Alawiyah, the Union of the Descendants of the Prophet. This organisation opposed attempts by the Irsyadis (followers of Al-Irsyad) to remove privilege position of the sayyid. ${ }^{29}$ Rabithah has an institution called al-Maktab al-Dāimi (Daily Office) which serves to preserve sayyid history and record their genealogy. In 1940, the institution recorded 17,764 sayyid with their genealogies from various parts of Indonesia. ${ }^{30}$

The different stance between Al-Irsyad and Rabithah Alawiyah led them to oppose each other either through words or actions. Their

\footnotetext{
${ }^{26}$ Badjerei, Al-Irsyad Mengisi, p. 32; Bisri Affandi, Syaikh Ahmad Syurkati (1874-1943): Pembaharu dan Pemurni Islam di Indonesia (Jakarta: Pustaka Al-Kautsar, 1999), p. 13.

${ }^{27}$ Mobini-Kesheh, The Hadrami Awakening, p. 56.

${ }^{28}$ Huub de Jonge, "Abdul Rahman Baswedan and the Emancipation of the Hadhramis in Indonesia," Asian Journal of Social Science, 32: 3 (2004), p. 378; Deliar Noer, Partai Islam di Pentas Nasional (Jakarta: Pustaka Utama Grafiti, 1987), p. 12.

${ }^{29}$ Jonge, Discord and Solidarity, p. 378.

${ }^{30}$ Rabithah Alawiyah, AD-ART Rabithah Alawiyah. n.d.
} 
debates were published in Arabic papers, pamphlets, and brochures where each group defended their position and attacked their rival. ${ }^{31}$ The debate revolved around three main areas of Hadhrami custom: "the kissing of sayyid's hands, the ban on marriage between a sayyids daughter and a non-sayyid, and the use of the title "sayyid".32 MobiniKesheh (1999) observed that the debate over sayyid status was expressed in terms of Hadhrami-ness. In this sense, each group claimed that they were more Hadhrami than others. To the sayyids, obedience to the traditional stratification system was the essence of Hadhrami identity, while for non-sayyids the tradition was imposed by sayyid whom they regard as "intruders" to Hadhrami society. In this regard, Irsyadis sought to be 'modern' while maintaining their Hadhrami identity. ${ }^{33}$ A culminating point of the debate was the decision of Al-Irsyad to desacralize the title "sayyid". Al-Irsyad's congress in 1931 in Batavia decided that the title sayyid was not exclusive to a particular group (sayyids) but could be addressed to anyone who deserves espect, regardless their lineage. For them, the title "sayyid" should be equated to "mister" or "sir" in general use. By this, Al-Irsyad suggested that any person has the right to use such a tittle. This decision appalled the sayyids who feared the loss of their aristocratic privileges. ${ }^{34}$ The sayyids fiercely rejected the idea and argued that "the title "sayyid" was long established by custom in Hadhramawt, in the Indies, and other parts of the Islamic world". ${ }^{5}$ Moreover, they contended that the title had to be preserved in order to follow Islamic law that especially applies to descendants of the Prophet, such as the law of kafa'ah (equivalence) in marriage. The title was important for sayyid because it could remind their offspring to undertake their religious responsibility in societies. ${ }^{36}$ The polemic between the two groups resulted in serious riots and violence. In Bondowoso, for instance, several Irsyadi who pushed forward during prayer in a mosque were killed by sayyids. ${ }^{37}$

\footnotetext{
31 Jonge, Discord and Solidarity, p. 82.

32 Mobini-Kesheh, The Hadrami Awakening, p. 92.

33 Ibid.

${ }^{34}$ Jonge, Discord and Solidarity, p. 82.

${ }^{35}$ Mobini-Kesheh, The Hadrami Awakening, p. 105.

${ }^{36}$ Ibid., p. 106.

${ }^{37}$ Jonge, Discord and Solidarity, p. 84.
} 
Both sayyids and Irsyadis petitioned the Dutch Government on the issue of sayyid status. The sayyids, under the Rabithah organisation, sought legal recognition of their title, but the Irsyadi asked the government to be neutral in the conflict by rejecting the sayyid's demands. The government finally decided that it would not fulfill the sayyid's wishes. The conflict was finally over due to the role of new generation of sayyids who preferred to focus on the issue of education rather than extending their battle with Irsyadi. ${ }^{38}$ In the meantime, younger generation Irsyadis, along with some progressive sayyid who were born in Indonesia (muwallad), opposed the division within Hadhrami community and sought to integrate them into Indonesian society by establishing the Persatoean Arab Indonesia (PAI), the Union of Indonesian Arabs. ${ }^{39}$

\section{Internal Divisions and Growing Sectarianism}

\section{The Current Sunni-Shi'a Division within Sayyid Community}

The friction within the Hadhrami-sayyid community at the present is among others due to the issue of Shi'ism. This tension has occurred at both the leadership and grassroots level. However, the dispute among sayyid leaders is more exposed in media than from the grassroots. Several sayyid told me that the doctrinal tension occurred in the community due to the rising Shi'ism in Indonesia in the wake of Iranian revolution in 1979. The charisma of Ayatollah Khomeini, who is also a sayyid, with his success in leading the revolution, made him an appealing figure among sayyid community in Indonesia. He was regarded as a brave Muslim scholar and leader who opposed a tyrant government, back up by US, only through sermons and brochures. ${ }^{40} \mathrm{~A}$ popular preacher in Malang, Habib Jamal b. Ba'agil, told me that the conversion of young Hadhramis to Shi'ism was also due to the absence of ulama idols from Hadhramawt who could become reference for Hadhrami-sayyids in 1980s and 1990s.41 This was the result of the severing of ties between Indonesia and Yemen after the Socialist won power in Sana'a from 1967 to 1990. This affected the conversion of young generations of sayyid to Shi'a. This was clear for instance, from

\footnotetext{
${ }^{38}$ Mobini-Kesheh, The Hadrami Awakening, p. 107.

${ }^{39}$ Jonge, Discord and Solidarity, p. 86.

40 Interview with Hasan Daliel Alaydrus, Jakarta, 28 January 2013.

${ }^{41}$ Interview with Habib Jamal b. Ba'agil, Malang, 25 March 2013.
} 
the story of Husein Shahab, who went to study in Iran several months after the revolution. His initial motivation to study in Qum was more educational than doctrinal. In time, though, he converted to Shi'ism. ${ }^{42}$

Conversion to Shi'ism has increased among Hadrami, as well Indonesians in general, after the return of the graduates from Iran. Many of them became preachers and writers, and founded Shi'ite educational institutions and religious learning centres. As Zulkifli has rightly observed, the majority of students at the Shi'i YAPI pesantren in Bangil have been dominated by Indonesian Arabs. ${ }^{43}$

The growing conversion of young sayyids to Shi'ism caused deepening concerns in Sunni-Shafi'i Hadhrami community. Some habaib told me that the Shi'a issue has led to disputes and splits within sayyid families. There are cases of Sunni parents repudiating their children who converted to Shi'ism. Several divorces also happened when one spouse found the other had converted to Shi'ism. ${ }^{44}$ Sayyid families who are tolerant to Shi'ism or seek to maintain harmony within their family tend to be silent on the matter if they know that one of their family members are Shi'a. In organisational and educational settings, tension also occurred. The leader of Ahlul Bayt Indonesia $(\mathrm{ABI})$, one of the main Shi'ite organisations in Indonesia, Habib Hasan Dalil al-Aydarus, was fascinated with Ayatollah Khomeini when he, along with his Sunni colleague, Habib Rizieq Shihab, studied in Saudi Arabia. Upon returning to Indonesia, he dedicated himself to teaching at his former school, Jamiat Khair in Jakarta. However, when the school's principal and teachers found that he had 'converted' to Shi'ism, he was denounced and eventually resigned. ${ }^{45}$ Habib Hasan later established Ahlul Bayt Indonesia together with his Shi'i friends.

\section{Albayyinat and Anti-Shi'a}

The vast majority of sayyid religious scholars and preachers in Indonesia maintain that their ancestors are Sunni. They emphasize that

\footnotetext{
42 Zulkifli, The Struggle of the Shi'is in Indonesia (Canberra: ANU E-Press, 2013), pp. 6162.

43 Ibid., p. 144.

44 Interview with Syafiq, Jakarta, 12 August 2015; Muhammad Alwi Al-Kaff, Jakarta, 13 August 2015.

${ }^{45}$ Interview with Syauqi, Jakarta, 2 February 2013.
} 
Sunni Islam is an integral part to the identity of Hadhrami sayyid ever since their ancestor's migration to Indonesia and until now. They regard Shi'a a new and disturbing development among sayyid. Most preachers I met argue that Shi'a is a deviant sect within Islam. In countering Shi'ism, most Sunni habaib prefer to focus on peaceful preaching and education rather than through a public agitation or vigilante action. Claiming to follow the ethics of the Tariqa 'Alawiyyab ('Alawi spiritual path), most habaib prefer not to mention their Shi'a rivals by name in their sermon. However, some habaib do openly oppose Shi'ism in their preaching and writings.

Habaib's resistance to Shi'ism took a tangible form with the establishment of Albayyinat in 1988. This movement was founded by several habaib in Java including Habib Ahmad b. Zein Al-Kaff of Surabaya, Habib Thohir b. Abdullah Al-Kaff of Tegal, Habib Abdul Qadir Al-Haddad of Malang, and Habib Ahmad Assegaf of Bangil.46 Although it was founded in 1988, its name began to appear in public after the fall of the New Order. Its website stated that the emergence of the group was driven by the growing development of Shi'ism in Indonesia bringing religious teaching that had 'deviated' from the Prophet's teaching. ${ }^{47}$ It asserted Shi'is condemn and insult the Companions of the Prophet. Albayyinat calls itself Sunni group that seeks to protect Sunni Muslims from the spread of Shi'ism. Despite the various types of Shi'ism, Albayyinat regards it as single face which is all deviant and, therefore, an enemy of Islam. The group's activities focus on socialization and preaching on the danger of Shi'a through publications and the internet, trainings, seminars, and sermons. The group has also built a collaboration with Muslims organisations, either traditionalist or Salafi, in opposing Shi'ism. Despite their limited activity, Albayyinat's voice is getting louder in media and has contributed in inciting intolerance and violence to Shi'a community.

The chairman of Albayyinat, Habib Achmad b. Zein Al-Kaff, has sharply criticized Shi'as and condemned Muslim leaders who he sees as tolerant to Shi'ism, including habaib. He has been constantly invited by various organisations, whether traditionalist or reformist to give antiShi'a talks and cadre training. He appealed to the solidarity of all Sunni

\footnotetext{
46 Interview with Habib Achmad b. Zein Al-Kaff, Surabaya, 13 March 2013.

${ }^{47}$ See Albayyinat. (n.d.). "Apa dan Siapa Albayyinat", available at $<\underline{\text { http://www.albay- }}$ yinat.net/ind1.html> accessed on 20 October 2014.
} 
Muslims, including the Salafis, to fight against Shi'a as a common enemy. Not only attacking the Shi'i leaders and their institutions, he also criticizes moderate Muslims who seek to build a harmony with Shia.

\section{Attacks against Fellow Habaib}

Criticizing and denouncing fellow habaib publicly is a recent phenomenon among babaib in Indonesia. This is largely due to theological issues. Habib Achmad of Albayyinat is a good case on this matter. In several public sermons and seminars, Habib Achmad strongly criticized fellow habaib who have converted to Shi'ism. He regards this phenomenon as a blight on sayyid community. He argues that Sunnism is the core identity of habaib since their earliest ancestor in Yemen, Ahmad b. Isa al-Muhajir. In a seminar entitled "Why Shi' are not Muslim" on February 2014 in Surakarta, Habib Achmad stated "if there are habaib becoming Shi'i, (it means) they have become traitors to their ancestor (the Prophet). If they do not live according to the path of "Alawiyyin, they then are not habaib anymore". ${ }^{48}$ In my interview, he expressed his dissatisfaction with the Rabithah Alawiyah which he accused of not serious in countering Shi'ism, despite its adherence to the religious principles of Sunni Islam. He urges the Rabithah to adopt the anti-Shi'i program that Albayyinat proclaims. He suspects that its failure to tackle Shi'sm is due to the fact that some Rabithah leaders have Shi'a relatives. He mentioned the case of the general chairman of Rabithah Alawiyah, Habib Zen Umar b. Smith, who has a Shi'a brother-in-law, a famous religious singer, Haddad Alwi. ${ }^{49}$

One of Habib Achmad's targets is the famous Muslim scholar and the prolific writer Professor Quraish Shihab, who is a sayyid. Quraish is a former rector of the State Institute for Islamic Studies (IAIN) of Jakarta (1992-1998) and a former Minister of Religious Affairs (1998). He pursued Islamic studies at the Al-Azhar University, Egypt, from

48 Kiblat. "Habib Zein Al-Kaff: Habib yang Jadi Syiah Pengkhianat Rasulullah", available at <http://www.kiblat.net/2014/02/03/habib-zein-al-kaff-habib-yang-jadisyiah-pengkhianat-rasulullah/> accessed on 7 June 2015. Habib Achmad's talks and interviews on Shi'ism is often exposed by conservative online media such as www.kiblat.net., www.voa-islam.com., www.arrahmah.com., www.hidayatullah.com., www.eramuslim.com., and www.antiliberalnews.com.

${ }^{49}$ Interview with Habib Achmad b. Zein Al-Kaff, Surabaya, 13 March 2013. 
undergraduate to doctoral level. Although Quraish is a descendant of the Prophet, he avoids using the tittle habib and does not wear specific clothing that identifies him as babib. ${ }^{50}$ Quraish is popularly known as a moderate ulama whose views and works have a wide appeal to many Muslims in Indonesia. He has produced numerous books on Islam and a complete volume of Qur'anic exegesis (Kitab Tafsir). Despite his moderate views, aspects of his thought have been criticized by Islamist and conservative groups in Indonesia. One of those is his Sunni-Shi' Holding Hands: Is it Possible? a book he writes to bridge the Sunnis and Shi'is. ${ }^{51}$ It examines the similarities and differences in terms of theological doctrines between the two groups. For Quraish, the difference between them is not significant, and therefore, he advocates unity and enjoins Indonesian Sunni Muslims to live in harmony with Shi'a. Habib Achmad condemned this idea of bridging (taqrib), and argued that Shi'as are non-Muslims due to their incorrect theology. He likens Sunni and Shi'a to water and oil that can never mix. This was due to the sharp differences between the two in both doctrinal pillars (ushul) and branches (furu). Habib Achmad suspects that the project of reconciling the two groups is part of a hidden Shi'a agenda aimed at taking over the Sunni majority in Indonesia. He also suspects that Quraish already was approached and funded by the Shi'is through their generous projects. ${ }^{52}$

Another target of Habib Achmad's criticism was the great leader (imam besar) of Islamic Defenders Front (Front Pembela Islam, FPI), Habib Muhammad Rizieq Syihab. Habib Rizieq, with his FPI, has acquired notoriety as a radical figure who fights against immorality and threats to Islam. He has been very critical of liberal Muslim thinkers and several groups considered as deviant such as Ahmadiyah. Despite his militant views and actions, Habib Rizieq still considers Shi'a as part of Islam. He divides Shi'i into two groups: the moderate Shi'i (mu'tadi) and the extremist Shi'i (gbulat). For Habib Rizieq, in spite of their high respect to Ali, the former group does not condemn the Companions of the Prophet and His wife, Aisha. They also do not attack Sunni Muslims in public. Moderate Shi'a, for him, are not deviant and are still

\footnotetext{
${ }^{50}$ Interview with Muhammad Quraish Shihab, Jakarta, 22 August 2013.

${ }^{51}$ M. Quraish Shihab, Sunnab-Syiah Bergandengan Tangan Mungkinkab?: Kajian atas Konsep Ajaran dan Pemikiran (Tangerang: Lentera Hati, 2007).

${ }^{52}$ Interview with Habib Achmad b. Zein Al-Kaff, Surabaya, 13 March 2013.
} 
within the straight path of Islam. However, for the second group, he considers it deviant since they condemn the companions of the Prophet and Aisha and readily attack Sunni Muslims in their sermons. ${ }^{53}$ Despite Habib Rizieq's criticism of 'extreme' Shi'a, he is still denounced by Habib Achmad, particularly for his attitude regarding the moderate Shi'is, and for his willingness to have Shi'i give sermons in his house. ${ }^{54}$

Since Albayyinat is a minor group it does not represent the habaib's radical attitude to Shi'ism. The organisation has no headquarter, clear structure, and mass-following, nor systematic mass mobilization. Most of anti-Shi'a campaign is expressed through sermons and books mostly by Habib Achmad. Although many Sunni habaib reject Shi'a, they do not express their rejection through public agitation and violence. They prefer to strengthen the Sunni belief of their community in order to protect them from Shi'a influences. However, Habib Achmad is popular among conservative habaib and Islamists especially with regard to his strong anti-Shi'ism.

Despite its organizational limit, anti-Shi'a campaign has helped to stigmatize and provoke violence towards Shi'is. One instance of their involvement in inciting hate and violence was the mob attack on Ponpes Darul Sholihin owned by Habib Ali b. Umar al-Habsyi, in Jember, East Java on 11 September 2013. This attack, however, was not mobilized by Albayyinat leaders. The attack was driven by the allegation that the pesantren had spread Shi'ism to its students. Habib Ali clarified that he and his teachers did not spread Shi'ism, but only taught Sufism and undertake healing practice in the pesantren. ${ }^{55}$ The Commission for the Disappearance and Victims of Violence (Kontras) found in the field that the false accusation was driven by competition and envy on the side of several local ustadz (religious preachers and teachers) in the area due to the success of Habib Ali in managing the pesantren and expanding its building facilities. The source from Shi'i

\footnotetext{
53 Interview with Habib Muhammad Rizieq Syihab, Jakarta, 4 April 2013.

${ }^{54}$ Interview with Habib Achmad b. Zein Al-Kaff, Surabaya, 13 March 2013.

55 Kontras. "Desakan Penyidikan Komprehensif Kasus Penyerangan Pondok Pesantren Darul Sholihin, Puger, Jember, Jawa Timur", available at $<$ http://www.kontras.org $/$ home $/$ index.php?module $=$ pers\&id $=1774>$ accessed on 7 June 2015. See also Republika. "Kontras Desak Penyelidikan Kasus Penyerangan Ponpes", available at < http://nasional.republika.co.id/berita/nasional/hukum/13/09/21/mtg6nx-kontrasdesak-penyelidikan-kasus-penyerangan-ponpes $>$ accessed on 8 July 2015.
} 
media, few blogs, and videos on Youtube informed that Habib Muhdhor al-Hamid, a vocal anti-Shi'i habib from Jember who is affiliated to Albayyinat, was involved in inciting the violence. ${ }^{56}$ It was reported that local preachers, who were hostile to Habib Ali, facilitated a public gathering several months before the incident and invited antiShi'a habaib from Albayyinat including Habib Achmad b. Zein Al-Kaff of Surabaya and Habib Muhdhor al-Hamid of Jember to give sermons on the danger of Shi'a to local Muslims. However, it cannot be proven whether their sermons were the major drive for the pesantren mob attack. In fact, the mastermind behind the attack was local preachers who facilitated Albayyinat leaders to give sermons on anti-Shi'ism.

The growing anti-Shi'a campaign by some habaib has not resulted in a larger conflict between Sunni and Shi'a within the sayyid community. The main reason is that sayyid community has been divided among themselves in responding to Shi'ism. The Rabithah Alawiyah itself has not declared officially that it rejects Shi'ism. Shi'a sayyids are tolerated to attend the Rabithah's social and religious events, although none of them have positions in the Rabithah. As the minority, the Shi'a leaders and scholars tend to use defensive strategy by clarifying perceived misunderstanding of Shi'ism and put forward the common platform and unity among Muslims. Their attempt has been also supported by moderate Sunni scholars such as Quraish Shihab and religious leaders from the Nahdlatul Ulama and Muhammadiyah.

\section{The Split of Al-Irsyad Al-Islamiyah}

Over the past decade, Al-Irsyad Al-Islamiyah has been divided into two camps: Al-Irsyad Al-Islamiyah and Perhimpunan Al-Irsyad. The former claims to be guard that maintains the original modernist spirit of the organisation, while the latter is the conservative faction, which is influenced by Salafi seeking to bring purification and more professional management within the organisation. I argue that while the leadership rivalry is the cause for the division, the more fundamental reason for the conflict is actually the contest for authority between the modernists and the young conservatives, each of which

\footnotetext{
56 See for instance < http://www.tvshia.com/indonesia/index.php/news/299-kronologi-kejadian-penyerangan-pp-darus-sholihin-dalam-rangka-peringatan-maulid-nabisaw-ke-28> accessed on 14 July 2015.
} 
does represent the teaching of the founder of Al-Irsyad, Imam Ahmad Surkati.

\section{Leadership Divide: A Chronology}

The leadership conflict started in the mid-1990s. This was driven by the dissatisfaction of a group of Irsyadis toward the leadership of Geys Amar who had been a three-time chairman since 1982. The antiGeys group wanted regeneration and religious purification in the organisation. At the Al-Irsyad congress in 1996 in Pekalongan, Geys Amar ran again for the chairmanship. His only rival, Muhammad Bawazir, withdrew the election in order to avoid conflict with Geys. Geys automatically won the vote for another term. Geys felt under pressure by some of his executive board whom he considered fanatics and trouble makers in the organization. ${ }^{57}$ Geys, therefore, in 1998 purged more than ten executive members, including his deputy chairman, Muhammad Bawazir. This removal led to the dissident group to hold an extraordinary congress in Tawangmangu, Central Java, on October 1999, resulting in the formation of a new rival AlIrsyad leadership. The newly elected chairman was Farouk Zein Bajabir. In the following year, the Geys' camp held a 37th congress in Bandung in which Hisyam Thalib was elected as the new leader while Geys became General Secretary.

Given that there were two leaderships of Al-Irsyad Al-Islamiyah, there was an attempt by the two groups at reconciliation through mediation. They agreed to organize a joint congress in Cilacap in 2002. In the congress, the majority of participants voted for Farouk from the conservative group. However, the old-guard was angered by their defeat. They regarded the congress unconstitutional and refused to accept the result. Both appealed to the high court in East Jakarta to validate their legal status. In 2004 the court ruled in favor of the modernists and declared the 2002 congress in Cilacap invalid. After their defeat, the conservatives established a new organisation called "Perhimpunan Al-Irsyad" (Al-Irsyad Association) by modifying the name and the flag of the organisation. The organisation has been registered by the Ministry of Law and Human Rights through a ministerial decision in 2013. Until then, there have been continuous attempts from both sides for reconciliation, with no avail.

\footnotetext{
${ }^{57}$ Interview with Geys Amar, Jakarta, 11 February 2013.
} 


\section{Stagnation, Irsyadi Identity, and Revival through Doctrinal Revitalisation}

Both the old modernist and the young conservative share a similar concern with Al-Irsyad's stagnation. Compared to another modernist organisation, Muhammadiyah, Al-Irsyad has experienced a very little organisational expansion or increase in the number of educational institutions and quality of its education. In 2009, Al-Irsyad has only 132 branches across 23 provinces, 8 hospitals in various cities, and 140 educational institutions from kindergarten to high schools. ${ }^{58}$ According to Slama, the limited expansion of Al-Irsyad is due to its failure "in recruiting substantial numbers of Indonesian Muslims from outside the Hadhrami community and is still widely perceived as an 'Arab' organization". ${ }^{59}$ Besides, Al-Irsyad schools also show poor performance compared to other Islamic schools due to the lack of human resources, limited support from Hadhrami community, and the lack of Irsyadi orientation in its curriculum. ${ }^{60}$ For the insiders however, AlIrsyad's decline was deemed to be the direct result of the lack of ideological adherence within the organisation and in its educational orientation. Put in different ways, many Irsyadis do not teach and implement the values of "Irsyadi ideology" at both organisations and education.

The two groups seek to revive the golden age of the organisation and its educational institutions as developed by Ahmad Surkati. They believe that $\mathrm{Al}$-irsyad has been in crisis, especially in terms of the ideological principles and the mastery of Arabic and Islamic studies. Some leaders told me that many young Irsyadis now no longer implement and understand Al-Irsyad's principles (mäbadi). Moreover, many young Irsyadis no longer comprehend Arabic and acquire Islamic knowledge. Therefore, there is a growing concern among Irsyadi leaders to revive the identity and skills of the Irsyadis.

The old Al-Irsyad leaders argue that the big challenge of the organisation is the doctrine of Salafi-Wahhabi. They believe that they

\footnotetext{
58 58Al-Irsyad. "Al-Irsyad Tidak Haramkan Pemilu dan Kafirkan Anggota DPR", available at $<\underline{\text { http: } / / \text { alirsyad.net/?s }=\text { sekolah }+ \text { cabang }+2009>\text { accessed on } 8 \text { July } 2015 .}$

59 Slama. "Hadhrami Moderns", p. 121.

60 Al-Irsyad. "Pemerintah Hanya Akui Al-Irsyad yang Disahkan Mahkamah Agung", available at $<$ http://alirsyad.net/pemerintah-hanya-akui-al-irsyad-yang-disahkan-mahkamah-agung/> accessed on 7 July 2015.
} 
are too many Irsyadis studied at Salafi educational institutions in Jakarta, such as the Institute of Islamic and Arabic Studies (Lembaga Ilmu Pengetahuan Islam dan Bahasa Arab/LIPIA). Some LIPIA graduates continued their study in Islamic universities in Saudi Arabia, Yemen and Afghanistan. At these institutions, they were influenced by the Salafi-Wahhabi teachings. Geys stated:

Those (Irsyadis) who studied in the Middle East -wittingly or notwere influenced by Wahhabi thought. This could be seen from the way they pray and the style of their clothes and appearance such as wearing trousers right to their ankles (isbāl), having long beards, and their wives wearing black veil. They behave as if the truth is only on their side. ${ }^{61}$

Noorhaidi Hasan's study on Salafi movement in Indonesia discovers that several leading Salafi leaders in Indonesia were Hadhrami Arabs and some of them were previously educated in AlIrsyad schools. ${ }^{62}$ According to the old Al-Irsyad leaders, when these young Hadhramis returned to Indonesia, they became active members and injected more conservative views that differ radically from traditional Irsyadi principles. For instance, these youths prefer to use ru'ya (sighting moon) instead of hisäb (modern calculation) on determining the coming day of Ramadhan month. Many of them also tend to segregate men and women in Al-Irsyad's events. For senior Irsyadi leaders, their views and attitudes were puritanical and contained seeds of radicalism and possibly terrorism. They regard their religious understanding as contrary to Irsyadi principles that teach adaptation to modernity. ${ }^{63}$ Geys Amar asserted that the conservative group tried to inject their Wahhabi teaching into young Irsyadis and hijack the organisation by running for leadership positions. In fact, the reason why he sacked more than ten executive members in 1998 from the organization was that because they bring in problems into the body. ${ }^{64}$

The old camp leaders feel that there are external and internal factors for the penetration of Wahhabism into the organization. The external factor has to do with the expansion of Salafism in Indonesia

\footnotetext{
${ }^{61}$ Gatra 26, 7 May 2009.

62 Noorhaidi Hasan. Laskar Jihad: Islam, Militancy, and the Quest for Identity in Post-New Order Indonesia (Ithaca: Cornell Southeast Asian Program, 2006).

${ }^{63}$ Interview with Said Sungkar and Zeyd Al-Hiyed, Jakarta, 16 April 2013.

${ }^{64}$ Interview with Geys Amar, Jakarta, 11 February 2013.
} 
through generous Saudi funding. According to Geys Amar, the Wahhabi infiltration came in through Saudi donation via the Religious Attaché of Saudi Arabia embassy in Jakarta. Donations were delivered to schools, pesantren, and mosques owned by Al-Irsyad. They also provide scholarships to those wanting to study Arabic course and Islamic studies in Indonesia, such as LIPIA, and to those who want to study in Saudi Arabia. ${ }^{65}$ I observed that several Irsyadis who studied in Saudi-funded institutions have become prominent preachers within the Salafi community in Indonesia. They include Yusuf Usman Baisa (the current chairman of the Perhimpunan Al-Irsyad, Farid Ahmad Okbah (the former member of Perhimpunan Al-Irsyad), ${ }^{66}$ and Ja'far Umar Thalib (the former principal of Al-Irsyad school in Tengaran and the founder of Laskar Jihad).

The second factor is to do with the puritan nature of the organisation and the lack of Irsyadi identity. One Irsyadi leader, Said Sungkar, said that it is understandable why Irsyadis easily moved to Wahhabi groups as both have similar ideals of religious puritanism, i.e returning to the Qur'an and Hadith. But while the Salafis are heavily reliant on religious texts, and thus rigid and textual, the Irsyadis are willing -despite being textual- to take into account external factors such as social reality and science in understanding the texts. He gives slavery as an example. For the Salafis -in contrast to the Irsyadisslavery is legal based on religious texts. ${ }^{67}$

Furthermore, younger Irsyadis seem uninterested in the organisation's identity and established ideology. Since Indonesian independence, the government demanded all schools, including AlIrsyad, to use Indonesian language as the primary language in learning activities. This affected Al-Irsyad schools which used Arabic as their main language. This was exacerbated by the fact that the founder of the organisation, Ahmad Surkati, did not leave obvious works that could become a doctrinal foundation. Unlike Muhammadiyah, AlIrsyad schools do not provide a particular subject related to the ideological principles that will become point of reference in their

\footnotetext{
65 Ibid.

66 Okbah actively promotes anti-Shi'ism through dakwah and urges Indonesian Muslims to join jihad in Syiria against the Assad regime. According to Sidney Jones, Okbah is an ex-member of Jemaah Islamiyah (JI) and Afghan veteran. See Sidney Jones, IPAC Report, 2 December 2013, p. 4.
}

${ }^{67}$ Interview with Said Sungkar, Jakarta, 16 April 2013. 
religious view and practice. Moreover, the 'secular' subjects are now more dominant than the religious ones because of the demands imposed by the government's national guidelines. ${ }^{68}$ In dealing with this situation, Al-Irsyad Al-Islamiyah has recently published a manual containing the organisation's principles and their explanation for Irsyadis aiming at strengthening their identity. The manual covers the source of Islamic law, aqidah/taubid (theology), ibädah (religious devotion), akbläk (ethics), al-musāwa (egalitarianism), knowledge, and modernity. ${ }^{69}$ To illustrate their approach in asserting their ideology, the chairman of Al-Irsyad Al-Islamiyah, Abdullah Jaidi stated in his foreword of the book:

Today, foreign thoughts have infiltrated the environment of AlIrsyad. The thoughts seem not in line with the mabadi' (principles) we hold. This infiltration takes two forms. The first is that which brings a stagnant condition (jumud) in which people only rely on the past and use taqlid (blind following), while the other is that which inclines toward liberal thought and could uproot us from our religious and historical values...Therefore, the central leaders of Al-Irsyad Al-Islamiyyah think that it is important to revive the identity (jati dirr) of al-Irsyad by enhancing its mabädi', which serves as the ideology of organisation, as well as developing the understanding of Islam which is adaptive and in line with the spirit of the changing time. ${ }^{70}$

Such statement is indicative of the old Al-Irsyad's worries concerning the advent of new thoughts perceived as a challenge to their religious identity. Abdullah classified two kinds of foreign thoughts that his organization should anticipate namely conservatism and liberalism. Although Abdullah did not specify what he means by these two streams of thought, it is clear that the former refers to Salafism, while the latter to liberal Islam. The book was published partly to avoid the previous precedent where young Irsyadis were influenced by Saudi Salafism. In terms of his rejection of liberal Islam, Abdullah has the same view with the young Al-Irsyad although his camp itself was accused of being liberal. In this context, liberal Islam is

\footnotetext{
68 Interview with Said Sungkar and Zeyd Al-Hiyed, Jakarta, 16 April 2013.

${ }^{69}$ Pimpinan Pusat Al-Irsyad Al-Islamiyah. Mabadi Al-Irsyad dan Penjelasannya (Jakarta: Al-Irsyad Al-Islamiyyah, 2012).

${ }^{70}$ Ibid., pp. 9-10.
} 
defined as that which prefers rationality over the normative doctrines of Islam. The mabadi, Abdullah hopes can provide guideline for the young Irsyadis in grasping the Al-Irsyad ideological principles and protecting them from foreign influences.

The rival executive board, Perhimpunan Al-Irsyad, sees leadership and doctrinal problem as the cause of the conflict. The leadership problem in their view lay in the style of leadership of Geys Amar, who was too dominant and not accommodative to young Irsyadi aspirations. As Geys had occupied four periods of leadership from 1982 to 2000, he was seen as resistant to organisational regeneration and innovation. The Perhimpunan group sees itself as idealists who have fought to improve the organisation through more professional management and the maintenance of Irsyadi basic principles (mabadi). ${ }^{71}$ Before the conflict, the Chairman Deputy, Muhammad Bawazir, and several executive members proposed to improve the organisation through the adoption of Standard Operating Procedures (SOP) and spelling out the authority and rights of chairman and other members. Geys approved this idea but later reneged, believing that the new rules limited his leadership. He felt under pressure and later removed several executive members. The Perhimpunan camp considered the reshuffle as the Amar's move to secure his position from internal threats. ${ }^{72}$

Apart from leadership issues, the Perhimpunan group also objects the doctrine of the main Al-Irsyad's camp. They reject accusation that they are Wahhabis who have radical understanding of Islam. They regard such accusation as slanderous and a vilification of their group. They fought back by stating that the old group is too loose in upholding and implementing religion. ${ }^{73}$ Yusuf suspected that the old camp was influenced by the ideas of liberalism and pluralism on the ground that the adapt to social reality and modernity in interpreting the religious texts. In Yusuf's view, the old leaders tend to favor hedonism (bura-bura) by mixing the interaction of men and women in Al-Irsyad's program activities and wedding parties. For the Perhimpunan camp, this contradicts the Al-Qur'an and Hadith. The Perhimpunan group, therefore, has sought to revive religious purification in the organization

\footnotetext{
71 Interview with Yusuf Usman Baisa and Husin Maskati, Jakarta, 4 July 2013; Muhammad Bawazir, Jakarta, 11 September 2015.

${ }^{72}$ Interview with Muhammad Bawazir, Jakarta, 11 September 2015.

${ }^{73}$ Gatra 26, 7 May 2009.
} 
by reminding the Irsyadis to uncompromisingly uphold the Qur'an and Hadith through education and dakwah. Yusuf regards the spirit of purification was the important principle of Al-Irsyad Al-Islamiyah laid down by the founder Ahmad Surkati. He sees the common platform between Al-Irsyad and Salafis in terms of ideology. ${ }^{74}$

Yusuf's puritanical views and his close connection to Salafi group indicate that he is a Salafi. His salafi inclination is clear on several grounds. Firstly, he follows the conservative views in several aspects. One of them is the strict segregation between men and women in public activities. I observed that he and several members of Perhimpunan also follow Salafi style of clothing such as wearing trousers right to their ankles (isbäh). Moreover, he regards Al-Irsyad as a Salafi in spirit. He even asked me to listen to Roja TV and Radio, one of important Salafi media in Indonesia, in order to know more about Al-Irsyad's views. Secondly, he holds an important roles in Salafi communities where he is often invited as speakers and preachers. Yusuf himself did not object to be called a Salafi, but he did not like to be called a 'Wahhabi'. This might be because the term Salafi sounds more positive than Wahhabi as the latter has become identical with the followers of Muhammad b. 'Abd al-Wahhab', themselves perceived negatively as radicals and even terrorists.

On negative note, Yusuf's arguments indicate that he misunderstood the modernist characters of Al-Irsyad laid down by Ahmad Surkati. His Salafi outlook led him to only pick up purification aspect of Al-Irsyad's doctrine and ignored its modern aspect such as upholding egalitarianism and the compatibility between Islam and modernity. His failure in understanding Al-Irsyad's modernity led him to accuse Geys Amar and his camp as liberal. Geys himself seems to follow the footstep of Imam Surkati. He and the old-camp still uphold religious purification as one part of Irsyadi identity. The recent manual of the old-camp even regards Islamic liberalism as the challenge of AlIrsyad besides conservative Salafism. However, the major problem of Geys lied in his too long-serving leadership and his failure to accommodate young Irsyadis' aspiration in developing the organisation and their schools. Instead, he exaggerated the danger of Salafiinfluenced Irsyadis and blamed them as the source of the organisation's decline.

\footnotetext{
${ }^{74}$ Interview with Yusuf Usman Baisa, Jakarta, 4 July 2013.
} 


\section{Conclusion}

This paper has examined the internal dynamics within the Hadhrami community from the colonial era till the present Indonesia. It concludes that the conflicts within Hadhrami community shifted from Hadhrami traditional stratification to Islamic doctrine. The coming of a new religious belief that challenges the privilege and authority of religious elites leads to a tension and division between the groups. In colonial era, Hadhrami community was consolidated in an attempt to gain equality and modern education (Hadhrami awakening) in the Netherland East Indies. This was inspired by Chinese awakening embodied in the foundation of modern associations and schools. This was also a response to a discriminative policy of the colonial Dutch that categorized the Arabs in the second class after Europeans. Following Hadhrami tradition, Hadhramis gave a privilege to sayyid group who was at the top strata of traditional hierarchy in their homeland. As the descendants of the Prophet, they enjoyed special treatment from other Hadhrami groups and local Muslims in the form of hand-kissing. However, the coming of recruited teacher from Mecca, Syekh Ahmad Surkati, who spread views of Islamic reformism, challenged the sayyid group. The reformist idea, which was adopted from Egypt thinkers, campaigned for egalitarianism (musawwa) among Muslims irrespective of their nationalities, class, and lineages. The challenge on the Hadhrami stratification finally divided the community into two organisations: Jamiat Khair and Al-Irsyad. Most of the nonsayyids who favor Islamic reformism joint the latter group. The Indiesborn Hadhrami, however, fed up with the conflict between their parents. They sought to unite Hadhramis from different groups and called them to consider Indonesia as their motherland. Their movement became tangible with the foundation of Indonesian Arab Union (PAI) where most of its members were muwallad (diasporaborn). This movement created a new division among Hadhramis, especially between the wulayati and muwallad members of PAI. This division, however, ended after the independence of Indonesia.

In the post-independence Indonesia, especially after 1980s, the new challenge has come again to the two Hadhrami groups. The rising globalisation avenues have facilitated the flowing of ideas and funding from the Middle East to Indonesia. The ideas of transnational Islamic movements such as Salafism and Shi'ism had been spreading among 
university students since 1980s and later gained freedom to establish various organisations after Soeharto era. Like other Indonesian Muslims, some young generations of Hadhramis were interested in the movements and join them. The charisma of Khomeini and his successful revolution attracted young sayyids to study in Iran and later converted to Shi'ism. This conversion struck the sayyid community which generally follows Sunni theology and Shafi'i legal school. Several conservative habaib emerged and addressed criticism to Shi'a sayyids and those moderate scholars, including habaib, who promote dialogue between the two groups. They assert Sunnism as the identity of sayyids and Indonesian Muslims. In this respect, traditional Sunnism becomes a solidarity rope among sayyids.

In the case of Al-Irsyad Al-Islamiyah, the conflict has happened in organisational level. The conflict was driven by doctrinal contestation between old-modernist and young conservative camp. The conflict was triggered by the reshuffle of several executive members by the longservice leader Geys Amar in 1998. Amar regarded the members as Salafi intruders who injected conservatism among Irsyadis. The conflict finally divides the organisation into two: Al-Irsyad AlIslamiyah and Perhimpunan Al-Irsyad. The former group claims to maintain Al-Irsyad from conservative Salafi influences while the latter group claims to revive the glory of the organisation through more assertive religious observance and more professional management. The key leaders were educated in the Saudi-funded Salafi educational institutions and were largely influenced by Salafism. They are cast as Wahhabi group trying to bring radical Islam into the organisation. In the meantime, the conservative camp views the old-modernist as liberal and pluralist and, hence, deviated from the true principle of AlIrsyad (mabadi). The two groups have competed for Irsyadi authority by selecting and reasserting the doctrinal principles of Al-Irsyad.

The new dynamics within Hadhrami community suggest that they have integrated in the broader landscape of Indonesian Muslims. The issue of conflict in the community is no longer imported from Yemen, but it emerges from what has been contested among Indonesian Muslims. The conflicts over Shi'ism and Salafi-Wahhabism, for instance, have occurred not only within Hadhrami community, but also within Indonesian Muslims as well. This is certainly connected to the changing development in the country where various Muslim groups from overseas, especially after the fall of Soeharto regime, have 
emerged and competed for Islamic authority in the public sphere. In this process, the encounter of transnational Islamic doctrines, be it from the Saudi Arabia or Iran, with the long-established local Islam have led to tensions and conflicts within Indonesian Muslims. []

\section{References}

\section{Books and Articles}

Affandi, Bisri. Shaykh Ahmad al-Surkati: His role in al-Irshad Movement in Java in the Early Twentieth Century. MA Thesis. Canada: McGill University, 1976.

--------. Syaikh Abmad Syurkati (1874-1943): Pembaharu \& Pemurni Islam di Indonesia. Jakarta: Pustaka al-Kautsar, 1999.

Badjerei, Husein. Al-Irsyad Mengisi Sejarah Bangsa. Jakarta: Presto Prima Utama, 1996.

Bamualim, Chaedar S. "Islamic Militancy and Resentment against Hadhramis in Post-Suharto Indonesia: A Case Study of Habib Rizieq Syihab and His Islamic Defenders Front." Comparative Studies of South Asia, Africa, and the Middle East, 31:2 (2011): pp. 267-281.

Bang, Anne K. Sufi and Scholars of the Sea: Family Networks in East Africa, 1860-1925. London: Routledge, 2003.

Berg, L.W.C.V.D. Hadramaut dan Koloni Arab di Nusantara. Jakarta: INIS, 1989. Translated from Le Hadhramout Et. Les Colonies Arabes Dans L'Archipel Indien.

Boxberger, Linda. On the Edge of Empire: Hadhramaut, Emigration, and the Indian Ocean, 1880s-1930s. Albany: State University of New York Press, 2002.

Bujra, Abdullah. The Politics of Stratification: A Study of Political Change in a South Arabian Town. London: Oxford University Press, 1971.

DPP Rabithah Alawiyah. Anggaran Dasar \& Anggaran Rumah Tangga Rabithah Alawiyah. Jakarta: Rabithah Alawiyah, nd.

Haikal, Husein. Indonesia-Arab dalam Pergerakan Kemerdekaan Indonesian (1900-1942). PhD thesis. Jakarta: The University of Indonesia (UI), 1986. 
Hasan, Noorhaidi. Laskar Jihad: Islam, Militancy, and the Quest for Identity in Post-New Order Indonesia. Ithaca: Cornell Southeast Asian Program, 2006.

Jones, Sidney. IPAC Report, 2 December 2013.

Jonge, Huub de. "Discord and Solidarity Among the Arabs in the Netherlands East Indies, 1900-1942." Indonesia, 55, April 1993.

. "Abdul Rahman Baswedan and the Emancipation of the Hadhramis in Indonesia." Asian Journal of Social Science, 32:3 (2004): pp. 373-400.

Leaman, Oliver. The Biographical Encyclopedia of Islamic Philosophy. London: Bloomsbury, 2006.

Mobini-Kesheh, Natalie. "Islamic Modernism in Colonial Java: The AlIrshad Movement." in U. Freitag and W. Clarence-Smith (eds), Hadhrami Traders, Scholars and Statesmen in the Indian Ocean, 1750s1960s. Leiden: E.J. Brill, 1997.

------. The Hadrami Awakening: Community and Identity in the Netherlands East Indies, 1900-1942. New York: Cornell Southeast Asia Program, 1999.

Noer, Deliar. Gerakan Modern Islam di Indonesia 1900-1942. Jakarta: LP3ES, 1980.

Pimpinan Pusat Al-Irsyad Al-Islamiyah. Mabadi Al-Irsyad dan Penjelasannya. Jakarta: Al-Irsyad Al-Islamiyyah, 2012.

Shihab, M. Quraish. Sunnah-Syiah Bergandengan Tangan Mungkinkab?: Kajian atas Konsep Ajaran dan Pemikiran. Tangerang: Lentera Hati, 2007.

Slama, Martin. "Indonesian Hadhramis and the Hadhramaut: An Old Diaspora and Its New Connections." Antropologi Indonesia, 29:1(2005): pp. 107-113.

"Paths of Institutionalization, Varying Divisions, and Contested Radicalism: Comparing Hadhrami Communities on Java and Sulawesi." Comparative Studies of South Asia, Africa and the Middle East, 31: 2 (2011): pp. 331-342.

-------. "Hadhrami Moderns: Recurrent Dynamics as Historical Rhymes of Indonesia's Reformist Islamic Organization AlIrsyad." in Gottowik, V. Dynamics of Religion in Southeast Asia: 
Magic and Modernity. Amsterdam: Amsterdam University Press, 2014.

Zulkifli. The Struggle of the Shi'is in Indonesia. Canberra: ANU E-Press, 2013.

\section{Magazines \& Websites}

Gatra No. 26, 7 May 2009.

Albayyinat. (n.d.). "Apa dan Siapa Albayyinat." Available at $<$ http://www.albayyinat.net/ind1.html $>$ accessed on 20 October 2014.

Al-Irsyad. "Al-Irsyad Tidak Haramkan Pemilu dan Kafirkan Anggota DPR." Available at <http://alirsyad.net/?s=sekolah+cabang+2009>_accessed on 8 July 2015.

Al-Irsyad. "Pemerintah Hanya Akui Al-Irsyad yang Disahkan Mahkamah Agung." Available at $<\underline{\text { http://alirsyad.net/pemerin- }}$ tah-hanya-akui-al-irsyad-yang-disahkan-mahkamah-agung $/>$ accessed on 7 July 2015.

Kiblat. "Habib Zein Al-Kaff: Habib yang Jadi Syiah Pengkhianat Rasulullah". Available at <http://www.kiblat.net/2014/02/03/habib-zein-al-kaff-habib-yang-jadi-syiah-pengkhianatrasulullah/ > accessed on 7 June 2015.

Kontras. "Desakan Penyidikan Komprehensif Kasus Penyerangan Pondok Pesantren Darul Sholihin, Puger, Jember, Jawa Timur." Available at $<$ http://www.kontras.org/home/index.php?modu$\underline{\text { le}=\text { pers\&id }=1774>}>$ accessed on 7 June 2015.

Republika. "Kontras Desak Penyelidikan Kasus Penyerangan Ponpes." Available at $<\underline{\text { http://nasional.republika.co.id/berita/nasional/- }}$ hukum/13/09/21/mtg6nx-kontras-desak-penyelidikan-kasuspenyerangan-ponpes $>$ accessed on 8 July 2015.

Tv Shia. "Kronologi Kejadian Penyerangan PP. Darul Sholihin Dalam Rangka Peringatan Maulid Nabi SAW Ke-28." Available at http://www.tvshia.com/indonesia/index.php/news/299-kronologi-kejadian-penyerangan-pp-darus-sholihin-dalam-rangkaperingatan-maulid-nabi-saw-ke-28> accessed on 7 July 2015. 
Syamsul Rijal

\section{Interviews}

Achmad Zein Al-Kaff, Jakarta, 13 March 2013

Geys Amar, Jakarta, 11 February 2013

Hasan Daliel Alaydrus, Jakarta, 28 January 2013

Husin Maskati, Jakarta, 4 July 2013

Muhammad Alwi Al-Kaff, Jakarta, 12 March 2013

Muhammad Bawazir, Jakarta, 11 September 2013

Muhammad Quraish Shihab, Jakarta, 22 August 2013

Muhammad Rizieq Syihab, Jakarta, 4 April 2013

Said Sungkar, Jakarta, 16 April 2013

Syafiq, Jakarta, 12 August 2015

Syauqi Al-Gadri, Jakarta, 2 February 2013

Yusuf Usman Baisa, Jakarta, 4 July 2013

Zeyd Al-Hiyed, Jakarta, 16 April 2013 